\title{
Nobreza e principais da terra América Portuguesa, séculos XVII e XVIII
}

\author{
Ronald Raminelli*
}

\section{RESUMO}

$\mathrm{O}$ artigo analisa a formação da nobreza colonial a partir de provimentos régios, das concessóes dos foros de fidalgo, títulos de cavaleiro das ordens militares e dos brasóes de armas. Essas mercês, porém, não originaram a nobreza de sangue, pois raras famílias tiveram condiçốes de manter as honras e os privilégios da nobreza por longo tempo. No ultramar a "nobreza da terra" náo se apoiava nos títulos, mas no patrimônio, no controle de postos da administração local, e, sobretudo, de patentes militares. Recorrendo à base documental e à historiografia, o artigo pretende comprovar que os títulos não eram a condição sine quo non para ascensão social na sociedade colonial. Em geral, somente ao final de sua trajetória de sucesso os súditos ultramarinos pleiteavam e recebiam as honrarias da monarquia.

Palavras-chave: nobreza; ascensão social; elites locais.

\section{Nobility and Local Elites. Portuguese America, $17^{\text {th }}$ and $18^{\text {th }}$ Centuries}

\section{ABSTRACT}

The article analyzes the formation of the colonial nobility through royal decrees, from the concessions of the title of Nobleman, of the titles of Knight of the Military Orders, and of coats of arms. These honors, however, did not originate the nobility of blood. In fact, few families were able to maintain the honors and privileges of nobility for a long time. Overseas, the "local nobility" did not rely on titles, but on assets, on the control of the local administration posts and, above all, on military ranks. Using documents and historiography, the article intends to prove that the titles were not a prerequisite for upward social mobility within colonial society. In general, only at the end of their successful lives did the overseas subjects claim and receive the honors of the monarchy. Keywords: nobility; upward social mobility; local elites.

DOI: http://dx.doi.org/10.1590/2237-101X01903809

Artigo recebido em 30 de janeiro de 2018 e aprovado para a publicaçáo em 18 de fevereiro de 2018.

${ }^{1}$ Universidade Federal Fluminense, Niterói, Rio de Janeiro, Brasil.

* Professor da Universidade Federal Fluminense. E-mail: rraminelli@uol.com.br. 


\section{Nobleza y señores de la tierra. América Portuguesa, siglos XVII y XVIII}

\section{RESUMEN}

El artículo analiza la formación de la nobleza colonial a partir de decretos regios, de las concesiones de los foros de hidalgo, de títulos de caballeros de las Ordenes Militares, y de los escudos de armas. Esas mercedes, sin embargo, no originaron la nobleza de sangre, pues raras familias tuvieron condiciones de mantener las honras y privilegios de la nobleza por largo tiempo. En el ultramar, la "nobleza de la tierra" no se apoyaba en los títulos, sino en el patrimonio, en el control de puestos de la administración local y, sobre todo, en rangos militares. Recurriendo a la base documental y a la historiografía, el artículo pretende comprobar que los títulos no eran la condición sine qua non para la ascensión social en la sociedad colonial. En general, solamente al final de su exitosa trayectoria, los súbditos ultramarinos pedían y recibían los honores de la monarquía.

Palabras clave: nobleza; ascensión social; élites locales.

Em Portugal a nobreza de sangue era a mais antiga e prestigiosa, destacava-se pela linhagem, por seus vínculos de sangue e lealdade ao monarca. Na época moderna, defendia-se inclusive a capacidade que tinham os líquidos corporais (sangue, sêmen e leite) de transmitir as qualidades e o poder de comando específicos da alta nobreza. Para alguns historiadores, essa naturalização da nobreza se remete à gênese da ideia de raça. ${ }^{2} \mathrm{Na}$ Idade Média, o nobre se fazia nos campos de batalhas, nos serviços dedicados aos reis. Entretanto, depois de consolidadas as casas régias, sobretudo na França e na Inglaterra, a habilidade militar não era mais suficiente para consolidar as dinastias. Na época das guerras de religião do século XVI, se difundiu mais intensamente a distinção do sangue. Essa transformação da ideia de nobreza também se verificou nos tratados portugueses, embora, na prática, fosse mais evidente na alta nobreza lusitana.

O sangue então legitimava as honrarias e os privilégios e marcava a distinção social da alta nobreza, da nobreza titulada. ${ }^{3} \mathrm{O}$ rei podia criar nobres e promover a ascensão social dos vassalos, mas raramente ele inseria um plebeu na alta nobreza. Assim, remunerava os militares e os homens de cabedal que se mostraram leais à causa régia. Sua capacidade de conceder títulos e privilégios estava intimamente relacionada ao fortalecimento de seu poder como soberano.

\footnotetext{
${ }^{2}$ Sobre o tema da raça, ver: JOUANNA, Arlette. O imaginário do sangue e de sua pureza na antiga França. Tempo, Niterói, n. 30, p. 21-40, 2011; BOULLE, Pierre-Henri. Race et esclavage dans la France de l'Ancien Régime. Paris: Perrin, 2007; BÖTTCHER, N. et al. (Coord.) et al. El peso de la sangre: limpios, meztizos y nobles en el mundo hispánico. Ciudad de México: El Colégio de México, 2011.

${ }^{3}$ OSÓRIO, D. Jerónimo. Tratados da nobreza civil e cristã. Lisboa: Imprensa Nacional/Casa da Moeda, 1996 p. 92 e 113-14; SAMPAYO, Antonio de Villasboas e. Nobiliarchia Portugueza: tratado de nobreza hereditária, \& política. Lisboa: Oficina Francisco Vilella, 1676, p. 148.
} 
Sem novos aliados, os reis tinham seu poder militar e administrativo limitado. Os tratados portugueses denominaram esse grupo de nobreza política. ${ }^{4}$ Eles não alcançavam rapidamente o topo da pirâmide social, mas detinham o capital simbólico suficiente para que seus filhos e netos continuassem a ascender entre os nobres. De fato, eles compunham a baixa ou média nobreza, vassalos providos pela monarquia com hábitos das ordens militares, foros de fidalgo, privilégios da Câmara do Porto, cargos na administração da monarquia no reino e no ultramar.

A nobreza de sangue e a nobreza política eram providas e reconhecidas como nobres e fidalgos pela monarquia. ${ }^{5}$ Sua legitimidade dependia entáo do jogo político entre os monarcas e seus vassalos. A terceira categoria de nobres não estava respaldada pelos privilégios cedidos pela monarquia. Aliás, juridicamente o grupo não era nobre. A nobreza da terra era composta por vassalos com postos nas câmaras municipais, com assento nas Misericórdias e Ordens Terceiras, e detinham terras, engenhos, escravaria, tropas e patentes militares. Esses súditos podiam contar, ou não, com títulos providos pela monarquia, pois seu poder de comando não raro era independente de títulos e privilégios cedidos pelo soberano. ${ }^{6} \mathrm{~A}$ nobreza da terra, ou também denominada "principais da terra" ou "melhores famílias", era a categoria mais difundida no Brasil colonial. Em geral, os principais da terra valorizavam mais suas patentes de capitáo de ordenanças do que os hábitos das ordens militares ou foros de fidalgo. A preferência tornou-se mais nítida a partir da segunda metade do século XVIII, quando as distinçôes entre cristâos-velhos e novos e a limpeza de sangue perderam paulatinamente a capacidade de hierarquizar a sociedade. Assim, o perfil da nobreza da terra me leva a perguntar se os títulos de fidalgo e cavaleiro concedidos pelo soberano português garantiam a liderança social às elites do Brasil colonial.

Para responder a esta pergunta, há que se fazer uma enorme investigação e consultar séries documentais parcialmente destruídas. A administração da monarquia e da igreja em Portugal e no Brasil nem sempre produziu e tampouco preservou dados sobre as suas elites, sobretudo quando se compara aos acervos da Nova Espanha e do Peru. Restaram aos historiadores brasileiros três séries documentais bastante heterogêneas, mas capazes de fornecer pistas seguras sobre a ideia de nobreza na América Portuguesa. Vale mencionar as matrículas da Casa Real, as habilitaçôes das ordens militares e as justificaçôes de nobreza. Os dois primeiros datam da segunda metade do século XVII e resultam da remuneração de serviços militares contra os holandeses. O terceiro conjunto documental se concentra entre $1750 \mathrm{e}$ 1807, pois o terremoto de Lisboa destruiu os documentos referentes ao período anterior.

\footnotetext{
${ }^{4}$ VERA, Álvaro Ferreira de. Origem da nobreza politica. Lisboa: Livro Aberto, 2005, p. 20-24.

${ }^{5}$ Neste artigo, faço a distinção entre nobre e fidalgo. O primeiro é um termo genérico enquanto o segundo refere-se sobretudo aos nobres de linhagem. O rei poderia conceder títulos a plebeus e os tornar nobres, enquanto os fidalgos eram filhos de nobres. Na prática, essa distinção era relativa porque os reis concediam títulos de fidalgo, ou foro de fidalgo, aos plebeus.

${ }^{6}$ ANTONIL, André João. Cultura e opulência do Brasil por suas drogas e minas. Lisboa: CNCDP, 2001 p. 70; SCHWARTZ, Stuart B. Segredos internos: engenhos e escravos na sociedade colonial. São Paulo: Companhia das Letras, 1988 p. 211.
} 


\section{Matrículas da Casa Real}

Entre 1641 e 1681, 244 militares receberam título de fidalgo pelos serviços militares. Junto à concessão da fidalguia, encontram-se descritos os serviços prestados, sobretudo o tempo e os lugares onde participaram de batalhas e cercos. ${ }^{7}$ Em geral, os beneméritos lutaram no Brasil e no Maranhão e, concomitantemente, no reino, contra os espanhóis, no Mediterrâneo, contra os turcos, em Flandres, contra os protestantes, na Índia e em Angola, contra os neerlandeses e demais opositores. A descrição dos feitos corrobora a importância das armas para se alcançar a nobreza em Portugal.

Em relação à filiação dos novos fidalgos, ${ }^{8}$ as matrículas da Casa Real nos permitem concluir que eram raros (17\%) os militares filhos de fidalgos. Quando se menciona a fidalguia paterna, ou melhor, o dado de que o pai era fidalgo, percebe-se que o filho recebeu o mesmo título. Assim, a honra do pai raramente promovia a ascensão do filho de segunda para primeira ordem, por exemplo. Existiam dois tipos básicos de fidalgo: os fidalgos de primeira ordem, os mais prestigiados, e os de segunda ordem. Em tese, os primeiros eram concedidos aos filhos de fidalgos, enquanto os segundos eram atribuídos aos plebeus. Os foros da segunda ordem, particularmente os cavaleiros fidalgos, perfazem $69 \%$ de todos os títulos concedidos. Entre os fidalgos de primeira ordem, somente $18 \%$ eram filhos de fidalgos.

Entre os 244 novos fidalgos, somente $11 \%$ já eram cavaleiros das Ordens de Cristo e Santiago. No entanto, entre esses 27 cavaleiros, 18 receberam o foro mais prestigioso, o de fidalgo cavaleiro. De todo modo, no cômputo geral, não era a filiação nobre determinante para se alcançar o título de fidalgo cavaleiro, mas certamente a relevância dos serviços prestados à monarquia. Assim, a linhagem e o sangue não eram a principal motivação para receber do soberano um título de nobreza no Brasil.

Entre os 14 fidalgos de primeira ordem identifiquei sem muito esforço três mestiços: Bento Maciel (fidalgo cavaleiro), Joáo de Albuquerque de Mello (moço fidalgo) e João Soares Cavalcanti (fidalgo escudeiro e fidalgo cavaleiro). ${ }^{9}$ Os dois últimos eram neto e filho mestiço de Jerônimo de Albuquerque Maranhão, descendentes, portanto, de Jerônimo de Albuquerque, o "Adão pernambucano". O patriarca era português e casou-se em $1547 \mathrm{com}$ Tabira, índia tabajara, depois nomeada Maria do Espírito Santo Arco Verde, e tornou-se progenitor de um importante ramo da aristocracia colonial. A família esteve intimamente

\footnotetext{
${ }^{7}$ Estudo quantitativo realizado a partir da edição de Luís Amaral e dos manuscritos do Arquivo Nacional da Torre do Tombo (ANTT), Livros de Matrículas dos Moradores da Casa Real. AMARAL, Luís (Ed.). Livros de matriculas dos moradores da Casa Real: foros e ofícios 1641-1744. Lisboa: Guarda-Mor, 2009. 2t.

8 "Existiam duas ordens de fidalgos, sendo a primeira superior à segunda. Na primeira, estavam o fidalgo cavaleiro, fidalgo escudeiro e moço fidalgo; na segunda, o cavaleiro fidalgo, escudeiro fidalgo e moço de câmara. Assim, o fidalgo cavaleiro era o título mais honroso, enquanto o moço de câmara o menos prestigioso.” RAMINELLI, Ronald. Nobrezas do Novo Mundo. Rio de Janeiro: FGV/Faperj, 2015, p. 33. ${ }^{9}$ ANTT, Livro de Matrículas dos Moradores da Casa Real, liv. IV, fols. 53v e 172.
} 


\section{NOBREZA E PRINCIPAIS DA TERRA \\ - América Portuguesa, séculos XVII e XVIII}

Ronald Raminelli

vinculada à expansão portuguesa em direção ao leste, à conquista do Maranhão frente aos franceses e, posteriormente, às vitórias contra os neerlandeses nas guerras de Pernambuco e do Maranhão. ${ }^{10}$

Fidalgo cavaleiro, Bento Maciel também era mestiço, filho do português e governador do Maranhão Bento Maciel Parente, e de uma índia de São Paulo. Sobre seu pai pesava o defeito mecânico, embora seus feitos militares o tenham tornado cavaleiro da Ordem de Cristo. Para além dos serviços paternos, Bento Maciel lutou contra os holandeses no Maranhão e contra os espanhóis ao atuar como sargento-mor em Elvas. Ao levar a Belém as boas novas da libertação da capitania do Maranhão do jugo neerlandês, o também cavaleiro da Ordem de Santiago, Bento Maciel, foi capturado pelos mouros e levado a Tetuão (Marrocos), onde padeceu de cruel cativeiro. Preso por quase dez anos, somente seria libertado mediante o resgate de 8 mil pesos. Para tanto, o Conselho Ultramarino avalizava a venda de suas propriedades na capitania do Maranhão. ${ }^{11}$ Ao contrário dos mestiços de brancos e índios, vale por fim destacar que os militares beneméritos pretos e indígenas não receberam matrículas na Casa Real, embora essa dádiva régia estivesse registrada em vários documentos e crônicas, como exemplifica a concessão feita a Henrique Dias, o herói negro das guerras de Pernambuco. ${ }^{12}$

Na América Portuguesa, a alta nobreza titulada restringia-se aos governadores-gerais e particularmente aos vice-reis, que aqui permaneciam somente por alguns anos. Faltam estudos, mas acredito que a nobreza de linhagem tinha participação reduzida na sociedade colonial. As limitaçóes para o acesso à alta nobreza impediam o seu alastramento no ultramar português porque os filhos raramente herdavam o foro de fidalgo e os hábitos de cavaleiro das ordens militares obtidos pelos pais. Poucas famílias conseguiram controlar os títulos de média e baixa nobreza por todo o período colonial. Assim, as linhagens não se sustentavam, as famílias logo perdiam as benesses cedidas pela monarquia. ${ }^{13}$ Ademais, ainda não se verificou se fidalgos e cavaleiros das ordens militares recorreram ao status de nobre para obter vantagens no controle de postos administrativos e proveitos econômicos como faziam as "grandes famílias" na Nova Espanha. ${ }^{14}$

\footnotetext{
${ }^{10}$ LACROIX, Maria de Lourdes Lauande. Jerônimo de Albuquerque Maranhão, guerra e fundação no Brasil Colonial. São Luís: Uema, 2006.

${ }^{11}$ Arquivo Histórico Ultramarino (AHU), Maranhão, doc. 296. Consulta do Conselho Ultramarino... Lisboa, 11 de setembro de 1651.

${ }^{12}$ RAMINELLI, Ronald. Nobrezas do Novo Mundo, op. cit. p. 175-205.

${ }^{13}$ SCHWARTZ, Stuart B. New World Nobility: Social Aspirations and Nobility in the Conquest and Colonization of Spanish America. In: CHRISMAN, Miriam Usher; GRÜNDLER, Otto (Ed.). Social Groups and Religious Ideas in the Sixteenth Century. Kalamazoo: The Medieval Institute Western Michigan University, 1978, p. 36.

${ }^{14}$ KICZA, John E. The Great Families of Mexico: Elite Maintenance and Business Practices in Late Colonial Mexico City. Hispanic American Historical Review, Durham, v. 63, n. 3, p. 429-457, 1982.
} 


\section{Hábilitaçóes das ordens militares}

Em Portugal, originalmente os títulos de cavaleiro e as comendas das ordens militares eram mercês régias cedidas aos leais vassalos que se destacaram nos serviços militares no norte da África e depois na Índia. Tal tendência era vigente no quinhentos, mas, no século seguinte, se iniciou uma virada no eixo do império colonial. Antes, os olhos do rei estavam voltados para as especiarias do Oriente, para a manutenção da rede comercial entre Lisboa e os mares do Oceano Índico. Após as perdas das praças orientais, o crescente comércio de açúcar e escravos tornou o Atlântico uma área colonial privilegiada da monarquia. Em princípio, os cavaleiros das ordens militares defendiam a cristandade e prestavam vassalagem ao papa. Lentamente, os cavaleiros perderam a aura religiosa e vincularam-se aos interesses monárquicos. Como administrador do patrimônio das ordens militares, o rei de Portugal empregou seus recursos para premiar os feitos dos aliados nos campos de batalha. ${ }^{15}$

$\mathrm{Na}$ América Portuguesa, cavaleiros e comendadores das ordens militares contavam com foro especial na justiça, pois somente poderiam ser processados pelo bispo ou pelo juiz dos cavaleiros. Náo poderiam ser presos na cadeia das câmaras e estavam, em princípio, isentos do pagamento dos dízimos. Vale mencionar que esses privilégios nem sempre se efetivaram. Os estudos sobre as ordens militares no Brasil tiveram dois enfoques básicos. Primeiramente dedicaram-se à análise da concessão régia de hábitos e comendas das ordens militares, notadamente da Ordem de Cristo. Nessa etapa, a monarquia valorizou méritos e serviços militares dos moradores das capitanias de Pernambuco e da Bahia, entre 1640 e 1680.

Aí, entre os beneméritos, destacam-se os membros da açucarocracia — senhores de engenho, plantadores de cana e seus parentes - , os militares de carreira e os comerciantes. As guerras de Pernambuco renderam aos principais militares, nove moradores da Bahia e de Pernambuco, as comendas das ordens militares, benesses das mais prestigiosas da monarquia portuguesa. As comendas serviram para remunerar militares que nem sempre estavam inseridos entre as elites tradicionais. Datada entre 1630 e 1654, a guerra de Pernambuco incentivou a monarquia portuguesa a remunerar os serviços de muitos militares, soma que alcançou o número de 323 hábitos das Ordens de Santiago, Avis e Cristo, concedidos no período entre 1641 e 1683. ${ }^{16}$

Em seguida, as investigaçóes sobre as ordens militares centraram-se no período pombalino e demonstraram uma alteração relevante na concessão dos hábitos. Nessa etapa, os moradores do reino e do ultramar, notadamente comerciantes e militares, tornaram-se cavaleiros mediante a compra da comprovaçáo de serviços militares. Para impulsionar o comércio e a real fazenda, o governo pombalino prometeu perdáo para o defeito mecânico e hábitos para

\footnotetext{
${ }_{15}$ DUTRA, Francis. Membership in the Order of Christ in the Seventeenth Century. The Americas, Washington, v. 27, p. 3-25, 1970; OLIVAL, Fernanda. As ordens militares e o Estado Moderno. Lisboa: Estar, 2001, p. 39-106.

${ }^{16}$ KRAUSE, Thiago Nascimento. Em busca da honra. São Paulo: Annablume, 2012, p. 94-96, 123 e 164-165.
} 
os interessados em comprar a nobilitação. Tinham de adquirir dez açóes da Companhia do Grão-Pará e Maranhão ou da Companhia de Pernambuco e Paraíba; ou entregar oito arrobas de ouro anuais nas Casas de Fundição da Capitania de Minas Gerais. ${ }^{17}$

A ideia de nobreza em Portugal e no Brasil torna-se mais evidente quando se examina as concessões envolvendo índios, mamelucos, mulatos e cristãos-novos. Embora impedidos pela norma das ordens militares, esse grupo heterogêneo recebeu do monarca títulos de cavaleiro devido aos relevantes serviços prestados durante as guerras. Os exemplos comprovam, mais uma vez, que em Portugal era mais importante a lealdade ao monarca do que o sangue nobre de seus antepassados. ${ }^{18}$

Para ingressar nas ordens militares e na Inquisição, os indivíduos deveriam demonstrar a sua limpeza de sangue e origem nobre, livres dos defeitos mecânicos e ofícios vis. Para tanto, informavam os nomes e as localidades onde viveram seus pais e avós paternos e maternos. Seus ascendentes eram então investigados para comprovar se eram pessoas cristãs-velhas, limpas de sangue e de geração, sem raça alguma de judeu, cristão-novo, mouro, mourisco, mulato, infiel ou de outra nação infecta, e de gente novamente convertida à santa fé católica. ${ }^{19}$ Em princípio, a origem gentia e as raças infectas inviabilizavam o gozo da honra, isençôes e liberdades inerentes ao título de nobreza. Para além dos índios, nem sempre os beneficiados com os hábitos de cavaleiro traziam a pureza de sangue e a nobreza exigidas pelas normas das Ordens Militares portuguesas.

Na década de 1710, o cônego dom Lázaro Leitão Aranha (1678-1767) tornou-se membro da Mesa da Consciência e Ordens. Aí organizou e classificou os arquivos da Mesa referentes ao ingresso de cavaleiros nas ordens de Cristo, Santiago e Avis, no período entre c. 1600 e 1731. Na oportunidade agrupou os processos a partir dos impedimentos, ou seja, dos problemas enfrentados pelos suplicantes quando ingressavam nas ordens. Estavam inabilitados os indivíduos com as seguintes características: minoridade ou idade avançada; ilegitimidade; maus antecedentes; falta de informaçôes sobre os antepassados; origem cristã-nova, muçulmana, gentia, africana e mulata; por fim os crimes de lesa-majestade. ${ }^{20} \mathrm{~A}$ partir das listas do cônego, localizei vários cavaleiros que, em princípio, estavam impedidos, mas que receberam a mercê de hábito graças à relevância dos serviços prestados à causa da monarquia.

\footnotetext{
${ }^{17}$ OLIVAL, Fernanda. O Brasil, as Companhias pombalinas e a nobilitação no terceiro quartel do setecentos. Anais, Évora, n. 8/9, p. 73-97, 1998-1999; PEDREIRA, Jorge Miguel Viana. Estrutura industrial e mercado colonial: Portugal e Brasil (1780-1830). Lisboa: Difel, 1994; STUMPF, Roberta Giannubilo. Cavaleiros do ouro e outras trajetórias nobilitantes. Belo Horizonte: Traço Fino, 2014.

${ }^{18}$ RAMINELLI, Ronald. Nobrezas do Novo Mundo, op. cit., p. 13-174; DUTRA, Francis. A Hard-Fought for Recognition. The Americas, Washington, v. 56, p. 91-113, 1999.

${ }^{19}$ DEFINIÇÓES e estatutos dos cavaleiros \& freires de N. S. Jesus Christo. Lisboa: Craesbeeck, 1628; DUTRA, Francis. Membership in the Order of Christ in the Seventeenth Century, op. cit., p. 18-19.

${ }^{20}$ DUTRA, Francis. Ser mulato nos primórdios da modernidade portuguesa. Tempo, Niterói, v. 30, 2011, p. 101; BRANCO, Manuel da Silva Castelo. Os trabalhos de D. Lázaro Leitão Aranha sobre as três ordens militares: Avis, Cristo e Santiago. In: FERNANDES, Isabel Cristina Ferreira (Ed.). Ordens militares, guerra, religião, poder e cultura. Lisboa: Ediçóes Colibri, 1999, p. 63-78.
} 
Para a doutrina oficial da Igreja Romana, os ameríndios não eram infiéis, mas gentios ou pagãos, condição primitiva dos católicos antes da evangelização. Diferentemente de judeus e mouros, os nativos do Novo Mundo desconheciam a palavra revelada e jamais podiam ser enquadrados como recalcitrantes ou apóstatas. ${ }^{21}$ A querela sobre a posição dos ameríndios na cristandade não teve tanta repercussão em Portugal, e embora não pudessem atuar como o sacerdote, eles tiveram algumas benesses das ordens militares.

Para melhor conhecer a dinâmica lusa de nobilitação, há que se analisar a concessão de hábitos e foro de fidalgo a índios, mulatos e pretos. Com a falta crônica de tropas portuguesas para enfrentar a invasão holandesa de Pernambuco, do Maranhão e de Angola, os governantes luso-brasileiros valeram-se das forças militares indígenas e pretas. Entre 1630 e 1654, a coroa lusitana teve o reforço de valorosos chefes indígenas que foram condecorados com hábitos das ordens militares. No entanto, vale indagar se os nobres indígenas desfrutavam a mesma honra recebida pelos demais luso-brasileiros.

Nove chefes indígenas tornaram-se cavaleiros das ordens militares lusitanas. Eles enfrentaram com sucesso as investigaçóes da igreja e sagraram-se puros de sangue e livres de defeito mecânico. Após 1640, intensificaram-se nas crônicas de guerra notícias sobre as mercês concedidas aos principais indígenas de Pernambuco e do Rio de Janeiro, mas, em menor escala, existiam ainda os pedidos e as mercês de hábitos cedidas aos militares pretos do Terço de Henrique Dias. ${ }^{22}$ Aos últimos, porém, o aumento do tráfico de escravos e a proliferação de cativos no império português tornaram difícil a concessão de títulos de cavaleiro e, por conseguinte, a transformação de ex-escravos em nobres, em cavaleiros das ordens militares.

Embora não fossem numericamente importantes, os indígenas alçados a cavaleiros demonstram a maleabilidade da ideia de nobreza em Portugal. A absorção de chefes indígenas às ordens militares ocorreu em conjunturas críticas para a monarquia portuguesa: na invasão francesa na baía de Guanabara; na guerra contra os holandeses em Pernambuco e Angola; e na guerra dos bárbaros - contra os índios do interior do nordeste. Assim, conclui-se que, após os grandes confrontos, aumentavam sensivelmente as concessôes de títulos.

Na baía de Guanabara, o chefe indígena Arariboia, batizado Martim Afonso de Sousa, combateu os franceses ao lado de Mem de Sá. Mesmo com nome cristão, ele era um grande guerreiro tupi e, como os demais, um canibal. Mesmo assim, como recompensa, recebeu de d. Sebastiáo, em 1571, o prestigioso hábito da Ordem de Cristo, além da nomeação de capitão-mor de sua aldeia. ${ }^{23}$ Sabedor de seu valor para o governo da capitania, Arariboia certamente pleiteou postos

\footnotetext{
${ }^{21}$ RAMINELLI, Ronald. Nobrezas do Novo Mundo, op. cit., p. 50; MARTÍNEZ, María Elena. Genealogical fictions. Stanford: Stanford University Press, 2008, p. 103.

${ }^{22}$ DUTRA, Francis. A Hard-fought for Recognition, op. cit., p. 91-113; MATTOS, Hebe. Black Troops and Hierarchies of Color in the Portuguese Atlantic World: the Case of Henrique Dias and His Black Regiment. Luso-Brazilian Review, n. 45, n. 1, p. 6-29, 2008.

${ }^{23}$ ANTT, Chancelaria da Ordem de Cristo (COC), livro 2, fol. 84 v.
} 
militares para seus familiares. Tempos depois, em 1644, Manuel de Sousa, descendente de Arariboia, foi condecorado pelo rei d. João IV com um hábito de cavaleiro. Com a pureza confirmada, o último seria sagrado cavaleiro por ter as qualidades requeridas pelo Tribunal da Mesa da Consciência e Ordens. ${ }^{24}$

Nesse mesmo momento, na capitania de Pernambuco, Antônio Felipe Camarão, herói indígena da guerra contra os neerlandeses, recebeu o título de dom, brasóes de armas, patentes militares, hábitos e comenda da Ordem de Cristo. Em boa parte as mencionadas benesses foram conservadas pelos seus descendentes. Membros da família Camarão, os chefes indígenas potiguares eram: d. Antônio Felipe Camarão, d. Diogo Pinheiro Camarão, d. João Antônio Camarão, d. Sebastião Pinheiro Camarão e Antônio Domingos Arco Verde Camarão. Eles atuaram nos postos de sargento-mor, capitão ou governador dos índios de Pernambuco entre 1635 e 1732 . Por quase cem anos, as patentes militares foram herdadas de pai para filho, formando uma linhagem militar e nobre, impulsionada pelos soberanos. ${ }^{25}$

Durante a guerra contra os holandeses, Felipe III e d. João IV prometeram hábitos das ordens militares e perdoaram os defeitos de dois índios, um mulato e um mameluco: Manuel de Sousa, Diogo Pinheiro Camarão, Manuel Gonçalves Dória e Bento Maciel Parente. Curiosamente, esses indivíduos eram oriundos de pontos equidistantes da América Portuguesa: Rio de Janeiro, Pernambuco, Bahia e Cabo do Norte/Maranhão. No entanto, nem todos sagraram-se cavaleiros, embora tivessem a mercê de hábito. Por certo não deram prosseguimento ao processo ou não receberam a habilitação da Mesa da Consciência e Ordens. Em suma, entre 1571 e 1721, a monarquia portuguesa concedeu a nove chefes indígenas os hábitos das ordens militares pelos seus valorosos serviços. A distribuição de mercês entre os indígenas era, porém, tema longamente debatido na Mesa da Consciência e Ordens que nem sempre concordava com as mercês de hábitos concedidas pelos monarcas. Indispensável à manutenção do império, a benevolência real ampliava as alianças entre a monarquia e seus fiéis vassalos ultramarinos. Ao premiar os feitos militares, os reis multiplicavam suas defesas e asseguravam o controle sobre os territórios.

Na Mesa da Consciência e Ordens há uma carta da princesa Margarida na qual ela defende que os hábitos das ordens militares foram estabelecidos desde seu princípio para premiar as pessoas que serviam na guerra. A princesa assim justificava a concessão de mercês a valentes guerreiros, súditos que nem sempre apresentavam as qualidades necessárias para ingressar na nobreza, ou melhor, na baixa nobreza. Sobre os índios, pairavam as dúvidas sobre a origem gentia e a recente conversão. A condescendência com os índios permite entender a nobilitação de mamelucos. Se os chefes indígenas estavam livres dos impedimentos de sangue, aos mestiços, filhos de portugueses com índias, a Mesa da Consciência e Ordens náo podia imputar a pecha de sangue impuro. Filho de governador, fidalgo e cavaleiro da ordem de Cristo, a origem

\footnotetext{
${ }^{24}$ ANTT, COS, livro 15, fol. 136v-137, 141-141v.

${ }^{25}$ MELLO, José Antônio Gonsalves de. Restauradores de Pernambuco; Filipe Camarão. Recife: Imprensa Universitária, 1967; RAMINELLI, Ronald. Nobrezas do Novo Mundo, op. cit., p. 155-174.
} 
de Bento Maciel Parente também propiciava sua elevação a cavaleiro. Os serviços de seu pai se somavam a seus próprios feitos, o que reforçava sua súplica para ser cavaleiro. ${ }^{26}$

A lógica talvez valesse para os mulatos. Por sua origem cativa e gentia, esses mestiços tinham grandes chances de ver negadas suas súplicas para ingressar na Inquisição como familiares e nas ordens militares. Como era o caso do cavaleiro Matias Vidal de Negreiros, filho bastardo e mulato de André Vidal de Negreiros, que fora governador de Pernambuco. Esse mulato recebeu de Sua Majestade o hábito da Ordem de Cristo, foro de fidalgo e a legitimaçáo da paternidade, mesmo após o falecimento do pai. ${ }^{27}$ Nesse caso, a "mulatice" e a bastardia não impediram que o filho de André Vidal de Negreiros, também herói das guerras de Pernambuco, recebesse, para além do prestigioso hábito, a patente de sargento-mor e capitão honorífico em $1694 .{ }^{28}$ Vale aqui reproduzir a conclusão de Fernanda Olival sobre a benevolência da coroa no momento de sagrar cavaleiro: “(...) não se nota por parte da Coroa um grande apego à ideologia da pureza de sangue, um fenômeno eminentemente popular e de pequenos setores das elites." ${ }^{29}$ No entanto, não considero correto atribuir somente aos populares e à pequena parte das elites o apego à pureza de sangue. Vale mencionar que Igreja, Inquisição, ordens militares, ordens terceiras, confrarias e universidades sempre demonstraram enorme interesse na identificação da origem cristã nova e cativa de súditos e fiéis.

\section{Justificação de nobreza}

No direito heráldico português, a justificação de nobreza constituía etapa primordial para obtenção de brasão de armas e de cargos na administração, privilégios que estavam, em princípio, ao alcance dos estratos mais altos da nobreza. ${ }^{30}$ Por linha paterna ou materna, todos os descendentes de homens abrasonados herdavam a distinçấo. No entanto, contrariando a lógica hereditária, o monarca podia conceder o brasão a súditos que tivessem prestado serviços sobretudo nas guerras, concedendo aos leais vassalos o título de fidalgo de cotas de armas, ou seja, a posição mais baixa entre os fidalgos capazes de receber o brasão.

Além de ser fidalga e pertencer à ordem mais distinta do reino, a família abrasonada dispunha do privilégio de vincular o brasão ao morgado, de trazer seus lacaios com librés divisadas pelas diversas cores de suas armas. Os membros da família podiam usá-los em arreios, sinetes e divisas durante as batalhas, em campos e escaramuças, exibi-los em suas casas, sepulturas, capelas e mais edifícios. Nesse processo, as falsificaçóes eram recorrentes

\footnotetext{
${ }^{26}$ ANTT, Mesa da Consciência e Ordens, Ordens Militares, Papéis Diversos, maço 20 n. 182. Veja também o documento n. 183.

${ }^{27}$ ANTT, Registo Geral das Mercês (RGM), Pedro II, liv. 9, fl. 209-209v (4/12/1694 e 11/12/1694).

${ }^{28}$ RAMINELLI, Ronald. Matias Vidal de Negreiros: mulato entre a norma reinol e as práticas ultramarinas. Varia Historia, Belo Horizonte, v. 32, p. 699-730, 2016.

${ }^{29}$ OLIVAL, Fernanda. As ordens militares e o Estado Moderno, op. cit., 344.

${ }^{30}$ SÃO PAYO, Marquês de. Do direito heráldico português. Lisboa: Centro Tip. Colonial, 1927, p. 21.
} 
e nos levam a indagar sobre as razôes para se subverter as normas. Valia a pena forjar um passado nobre, pagar genealogistas e testemunhas para criar antepassados saídos da alta fidalguia? Com certeza, os brasóes concediam prestígio às famílias e facilitavam a ascensão social de novos ricos.

Para tornar seus resultados mais sólidos, a pesquisa deve contar com documentos cartoriais e eclesiásticos, sobretudo inventários e testamentos, registros de batismo, casamento e óbito. Nesse sentido, tentei realizar levantamento de dados sobre os brasonados no site Family Search ${ }^{31}$ e encontrei poucos nomes. Devido à limitação, a abordagem da pesquisa deveria ser alterada, pois seria inviável examinar todos os brasonados. Por conseguinte, ao analisar somente algumas trajetórias, o espectro da investigação fica muito limitado, e seus resultados dificilmente poderiam ser generalizados. Por essa razão, a análise aqui apresentada está baseada exclusivamente nos papéis referentes à concessão do brasão de armas.

A concessão dessa mercê era dependente da comprovação da linhagem dos suplicantes. Se os autos seguissem essa exigência, o presente estudo não seria tão dependente da inclusão de dados provenientes de outros fundos documentais. Conforme mencionado em seguida, os brasōes eram concedidos sem a obediência das normas. Para além da mencionada lacuna, há que se analisar os dados e os poucos documentos anexados aos processos. Aí devem existir inúmeras falsificaçôes. Para identificá-las, a pesquisa deve consultar fundos documentais portugueses, espanhóis e franceses, pois os autos se remetem a ancestrais muito remotos. Os acervos portugueses e brasileiros são bastante lacunares sobre as trajetórias das elites, dificultando tanto a produção de sua história quanto a comprovação das falsificaçôes. Assim, devido à péssima preservação, existem poucos estudos sobre as nobrezas em Portugal e no Ultramar, mas a precariedade é ainda maior sobre a média e baixa nobrezas. Por conseguinte, é quase impossível estudar as falsificaçôes nos papéis referentes às concessôes de brasôes devido à precariedade dos acervos.

Certamente a imprecisáo dos autos de justificação da nobreza permitiu a alguns suplicantes criar genealogias retumbantes como o doutor Ignacio Teixeira da Cunha, presbítero e abade da paroquial de São João da Cova em Braga, natural da freguesia de Sáo Gonçalo da Cachoeira do arcebispado da Bahia, pois consta ser descendente de d. Isabel Pereira, "irmá do condestável d. Nuno Álvares Pereira, todos descendentes da primeira e mais ilustre fidalguia e nobreza destes reinos". A mesma ascendência justificava a fidalguia de suplicante Luiz Teixeira da Cunha Coutinho Carvalho e Abreu, natural de São Gonçalo dos Campos, vila da Cachoeira, arcebispado da Bahia. ${ }^{32}$ Enfim, se esses súditos tinham ou não antepassados tão ilustres nada se pode comprovar.

\footnotetext{
${ }^{31}$ Ver: https://www.familysearch.org/.

32 BAENA, Visconde de Sanches de. Archivo heráldico-genealógico. Lisboa: Typographia Universal, 1872, p. 267 e 457.
} 
Entre 1750 e 1807, o rei de armas de Portugal emitiu 1.385 cartas de brasão de armas, sendo 17\% dos brasões (239) aos súditos ultramarinos, 16\% (219) aos da América Portuguesa..$^{33}$ Entre os ultramarinos armoreados, os brasílicos eram 91,3\%, mas tinham presença bastante reduzida quando comparados aos do reino. ${ }^{34}$ Essa evidência reforça a premissa de que a nobilitação dos súditos se fazia maciçamente na metrópole. No ultramar lusitano, as concessóes se faziam com esta distribuição geográfica: Bahia 21\% (54 vassalos); Pernambuco 14\% (37); Rio de Janeiro 13\% (35); Maranhão 6\% (16) e São Paulo 6\% (15). Nas demais conquistas lusas, destaca-se Angola, com 4\% (11). A distribuição de brasôes no tempo evidencia a enorme incidência de carta de brasão de armas e justificaçôes na regência joanina (1792-1807), período sacudido pelas revoluçôes na França e no Haiti. ${ }^{35}$ A instabilidade política justificava a concessão de número crescente de brasão de armas.

Nos processos de justificaçáo de nobreza, os pernambucanos apresentam-se como a nobreza mais antiga, com altos índices de referências paternas e de antepassados ilustres. Encontram-se aí oito súditos da família Albuquerque e seus serviços prestados contra os holandeses em meados do século XVII. As famílias Maciel Monteiro e os Fonseca Galvão não dispunham da mesma honra, tampouco constavam da genealogia de Borges da Fonseca. De todo modo, estavam na lista do visconde quatro irmáos da primeira família e dois da segunda. Eles integraram-se aos principais da terra da capitania de Pernambuco depois de $1750 .^{36}$

Mencionados por Borges da Fonseca, os membros das famílias Albuquerque, Cavalcanti, Borges da Fonseca, Carneiro da Cunha, Bandeira de Mello, Campello, Uchoa e Paes Barreto se valeram dos feitos militares de seus antepassados para solicitar os brasóes. ${ }^{37}$ Vale ainda mencionar que, com exceção dos Albuquerque, as demais famílias estão na lista de brasonados com somente um representante. Enfim, os brasóes de armas cedidos aos ilustres moradores de Pernambuco estavam em larga medida baseados na tradiçấo, nos feitos heroicos das guerras contra os holandeses e em serviços militares posteriores. De todo modo, percebe-se uma renovação dos principais da terra evidenciada pelas famílias Maciel Monteiro e Fonseca Galvão.

Entre os vassalos do Maranhão (16 autos), se destacam duas famílias: os descendentes de Diogo Campos Moreno, com seis representantes, e de Lourenço Belfort, com quatro

\footnotetext{
${ }^{33}$ Este corte cronológico refere-se aos processos posteriores ao terremoto de Lisboa e se iniciam por volta de 1757.

${ }^{34}$ Devido ao caráter lacunar das informaçóes sobre os brasonados ultramarinos arrolados pelo visconde de Baena, procurei complementar os dados recorrendo aos processos de justificação da nobreza dos Feitos Findos, sobretudo quando os vassalos estavam em ambas as fontes documentais. Em uma amostra de cerca de 50 autos, percebi que a precariedade dos dados não se originava da pesquisa insuficiente do visconde, mas dos próprios autos. Ver: BAENA, Visconde de Sanches de. Archivo heráldico-genealógico, op. cit.; RAMINELLI, Ronald. Justificando nobrezas: velhas e novas elites coloniais. História, São Paulo, v. 35, p. 1-26, 2016.

${ }^{35}$ MAXWELL, Kenneth. A devassa da devassa. Rio de Janeiro: Paz e Terra, 1978, 233-271.

${ }^{36}$ Para família Maciel Monteiro, ver: AHU, Pernambuco, docs. 12915, 13735, 13934, 14827 e 15965. Para família Fonseca Galvão, AHU, Pernambuco, docs. 3639, 4022, 4841, 5419, 6621, 7330, 7375, 7972, 8325 e 8404.

${ }^{37}$ FONSECA, Antônio J. V. Borges da. Nobiliarchia pernambucana. In: Anais da Biblioteca Nacional, Rio de Janeiro, v. XLVII, p. 52, 66, 142, 184 e 199, 1925.
} 


\section{NOBREZA E PRINCIPAIS DA TERRA

representantes. As origens da primeira família remontam à conquista do Maranhão e aos combates contra os franceses, ao sargento-mor Diogo Campos Moreno, natural de Tanger e militar com experiência nas guerras em Flandres. Em 1602, veio para Pernambuco no governo de Diogo Botelho (1601-1608) e em seguida participou ativamente da conquista do Maranhão. ${ }^{38}$ A segunda família descende de Lancelot (Lourenço) Belfort, irlandês nascido em Dublin e morador de Lisboa. No Maranhão a partir 1736, construiu vasto patrimônio, muitas terras e um grande engenho de açúcar. ${ }^{39} \mathrm{Na}$ justificação da nobreza de seus descendentes, ainda consta que o patriarca da família detinha a patente de mestre de campo. Mas o ingresso nas armas foi tardio, depois de 60 anos. Lourenço então tornou-se militar não pelos seus feitos em guerras, mas pela honra e pela riqueza acumuladas ao longo da vida.

Para além das duas famílias, estavam entre os abrasonados do Maranhão o tenente dos granadeiros do regimento de São Luís, o fidalgo e cavaleiro de Avis Francisco Xavier de Miranda. Com sólida carreira militar, Miranda era filho do capitão-mor José Machado de Miranda, cidadão de São Luís, procurador da Coroa e Fazenda e terceiro neto do capitão-mor Manuel Pita da Veiga, militar atuante nos anos de 1640. Antes de obter a carta de brasão de armas, o tenente escreveu ao Conselho Ultramarino para pleitear tanto a inclusão de sua família no rol da nobreza do Maranhão quanto o hábito da Ordem de São Bento de Avis. ${ }^{40}$ Com carta de recomendação de d. Rodrigo de Sousa Coutinho e um fabuloso patrimônio, o comerciante português radicado no Maranhão, José Gonçalves da Silva, tinha muito prestígio na corte, embora não contasse com a boa linhagem de seus antepassados. A honra acumulada recentemente provinha de seus inúmeros aportes financeiros durante as invasóes francesas. Pelo apoio na guerra, recebeu um hábito da Ordem de Cristo e o brasão de armas aos 50 anos. ${ }^{41}$ Nesse caso, mais uma vez, a patente de coronel das milícias da cidade de São Luís funcionava como um título honorífico, pois o comerciante não seguira carreira militar antes de receber a patente.

Salvo o rico comerciante de grosso trato, os demais brasonados do Maranhão nasceram na mesma capitania, notadamente em São Luís e Alcântara. No conjunto, quatro receberam o brasão entre 24 e 29 anos, todos descendentes de Diogo Campos Moreno ou Lourenço Belfort. Com idade mais avançada, entre 40 e 60 anos, encontram-se seis descendentes das novas e velhas famílias. ${ }^{42}$

Na capitania da Bahia, as linhagens mais tradicionais não estavam nos autos de justificação da nobreza. À época, os principais proprietários de terras, senhores de engenho e comerciantes

\footnotetext{
${ }^{38}$ VARNHAGEN, Francisco Adolfo de. História Geral do Brasil. Belo Horizonte: Itatiaia; São Paulo: Edusp, 1981, p. 55. v. 1, t. 2.

${ }^{39}$ COUTINHO, Mílson. Fidalgos e barôes: uma história da nobiliarquia luso-maranhense. São Luís: GEIA, 2005, p. 97-98.

${ }^{40}$ As referências ao capitão-mor datam dos anos de 1640, ver os seguintes documentos: AHU, Maranhão, docs. 188, 189, 229, 230, entre outros. Ver ainda: Parecer do Conselho Ultramarino do príncipe regente, 1 de agosto 1799, AHU, Maranhão, doc. 8352.

${ }^{41}$ BAENA, Visconde de Sanches de. Archivo heráldico-genealógico, op. cit., p. 385.

${ }^{42}$ COUTINHO, Mílson. Fidalgos e barōes: uma história da nobiliarquia luso-maranhense, op. cit., p. 66-286.
} 
de grosso trato não pediram ao soberano os brasóes. Aliás, os baianos forneceram dados insuficientes sobre sua qualidade. Esse vazio se evidencia quando se constata que cerca de $25 \%$ dos autos não fornecem dados sobre os pais, tampouco dos antepassados. Os principais da terra e as altas patentes militares eram raras entre os abrasonados. ${ }^{43}$ As elites baianas talvez dessem pouca relevância aos brasôes de armas quando comparadas às melhores famílias do Maranhão. Entre os baianos havia apenas dois sargentos-mores e os demais eram capitães e oficiais, mas todos das tropas auxiliares e das ordenanças.

Metade dos baianos brasonados era composta por militares. A outra parte era composta por comerciantes, bacharéis, filhos de militares e homens abastados sem inserção social definida. De forma extraordinária, muitos receberam a carta de brasão sem informar sua qualidade e a origem de seus antepassados. Ainda nos escapa a idade média para receber o brasão dos suplicantes da Bahia. Nesses processos, nem sempre se registraram o nascimento do suplicante. A carência de dados ainda nos leva a cogitar sobre a possibilidade de homens ricos e de origem mecânica comprarem um parecer positivo das autoridades locais e apresentar aos reis de armas.

Passo então a analisar um caso bastante emblemático. A família Santos Marinho e Castro não consta da genealogia de Jaboatão, ${ }^{44}$ mas tem quatro representantes entre os brasonados. Nesse grupo estavam três filhos de Antônio Cardoso dos Santos, coronel, cavaleiro da Ordem de Cristo, tesoureiro da bula da Santa Cruzada, tesoureiro geral da Junta da Real Fazenda e negociante de grosso trato. ${ }^{45}$ Em setembro de 1799, Pedro Marinho e Castro enviou requerimento ao príncipe regente para receber hábito da Ordem de Cristo e menciona que seu falecido pai estabeleceu em Salvador "uma das maiores Casas de Comércio de toda a América que girava avultados cabedais para os portos da Europa e África, com quem pagou para a Real Fazenda imensa soma de Direitos (...)". ${ }^{46}$

Dispondo de fortuna, o comerciante ocupou vários postos na administração e sempre viveu a lei da nobreza. O governador Manuel da Cunha e Meneses (1774-1779) criou um regimento da infantaria auxiliar, chamado dos úteis, e nomeou o pai para atuar como tenente coronel. Depois de cinco anos no posto, tornou-se coronel agregado do regimento. O pedido de mercê de Pedro Marinho revela a extraordinária ascensão social e o enobrecimento dos comerciantes. A riqueza permitia não somente controlar postos de prestígio e poder na administração, mas também receber títulos de cavaleiro e brasóes de armas. Demonstra ainda como os homens de cabedais passavam a controlar soldados e disputavam com os militares de carreira as altas

\footnotetext{
${ }^{43}$ A afirmação está estribada nos estudos de: KENNETH, John Norman. Bahian Elites, 1750-1822, Hispanic American Historical Review, Durham, v. 53, n. 3, 1973, p. 416-424; BORGES, Eduardo José Santos. Viver sob as leis da nobreza. Tese (Doutorado) — Programa de Pós-graduação em História, Universidade Federal da Bahia (Ufba), Salvador, 2015, p. 141, 237 e 247.

${ }^{44}$ CALMON, Pedro. Introdução e notas ao catálogo genealógico das familias de Frei Jaboatão. Salvador: Empresa Gráfica da Bahia, 1985.

${ }^{45}$ BAENA, Visconde de Sanches de. Archivo heráldico-genealógico, op. cit., p. 23-24 e 34.

${ }^{46}$ Requerimento de Pedro António Cardoso dos Santos Marinho de Castro, [ant. 4 de setembro de 1799], AHU, Bahia, doc. 15094.
} 
patentes das tropas auxiliares. Nessa família, única nesse conjunto documental, existem duas mulheres (avó e neta) agraciadas com brasão de armas. Entre 1790 e 1802, quatro membros da família tiveram a graça de exibir seus brasóes, demonstrando a trajetória rápida de enobrecimento impulsionado tanto pelo mérito quanto pelo vasto patrimônio. ${ }^{47}$

Entre os moradores abrasonados do Rio de Janeiro estavam 22 militares (57\%), sendo seis oficiais de alta patente da tropa paga. Se na Bahia eram apenas dois, em Pernambuco um, no Maranhão não existiam os altos oficiais entre os suplicantes. A mencionada distribuição não surpreende, porque a cidade do Rio de Janeiro era a capital do Estado do Brasil. No entanto, os militares aí presentes não apresentavam a qualidade de seus antepassados para obter o brasão, não estavam inseridos na antiga nobreza da terra. Dos 22 oficiais, somente sete tinham pais e avós militares. Assim, nos autos de justificação da nobreza, os militares do Rio de Janeiro não apresentaram uma longa filiação, ou seja, antepassados para além dos avós. Pertenciam, então, às famílias que se inseriam no oficialato nos últimos 50 anos. Tampouco apresentavam serviços nas guerras contra os holandeses em Pernambuco, Angola e Bahia, contra franceses na tomada da baía de Guanabara no início do século XVIII e contra os castelhanos nas fronteiras do sul. Em geral, os suplicantes da capitania do Rio de Janeiro apresentaram provas de nobreza ainda mais frágeis, porque $43 \%$ não forneceram dados sobre os pais, enquanto $51 \%$ não mencionaram os demais antepassados.

Encontrei dois suplicantes da família Amaral Gurgel ${ }^{48}$ que não recorreram aos feitos da casa para justificar a nobreza, embora a família fosse da maior importância desde o início do século XVII. O primeiro era o capitão-mor da vila de Parati, Francisco Carvalho da Cunha Amaral (Gurgel), que indicou o pai como coronel e a mãe como membro da mencionada família, mas subtraiu do seu nome o Gurgel. ${ }^{49} \mathrm{O}$ segundo era o cavaleiro da Ordem de Cristo José Viana do Amaral Rocha, não citado por Rheingantz. ${ }^{50}$ Ele se diz descendente do capitão João Batista Jordão e sua esposa Ângela Arã do Amaral, filha de Touvem Gurgel (Toussaint Grugel), natural do reino de França. Pelo sobrenome Rocha se originava do fidalgo francês Monsieur de la Rocha que passou a Portugal "nas guerras que tinha naquele tempo" e se intitulou conde de Quinzal. Há que se investigar por que ambos não exaltaram o patrimônio e o poder da família Gurgel para justificar a nobreza. ${ }^{51}$

\footnotetext{
${ }^{47}$ Idem.

${ }^{48}$ BAENA, Visconde de Sanches de. Archivo heráldico-genealógico, op. cit., p. 188 e 427.

${ }^{49}$ Há vários registros de mercês em seu nome: Carta padrão de tença e hábito, ANTT, Lisboa, Registro Geral das Mercês de D. João V, liv. 8, f. 290; Carta patente de capitão-mor da Vila de Paraty e hábito da Ordem de Cristo, ANTT, Lisboa, Registro Geral das Mercês de D. José liv. 3, f. 318.

${ }^{50}$ RHEINGANTZ, Carlos Grandmasson. Primeiras famílias do Rio de Janeiro (séculos XVI e XVII). Rio de Janeiro: Livraria Brasiliana Editora, 1965-1967, p. 324-340. v. 2.

${ }^{51}$ Nesta investigaçáo encontrei Francisco Carneiro da Cunha Amaral, não mencionado por Baena e Rheingantz. Embora precise ler o processo, tenho quase certeza de que é mais um Amaral Gurgel. ANTT, Lisboa, Justificação da Nobreza, Feitos Findos, 10, 29.
} 
Como na Bahia, muitos suplicantes do Rio de Janeiro eram militares de tropas auxiliares e das ordenanças e apenas alguns pertenciam às mais tradicionais famílias da capitania. Seriam os brasóes distinções sem importância para a antiga nobreza da terra? Os negociantes de grosso trato Brás Carneiro Leão e seu filho Fernando Carneiro Leão receberam cartas de brasão de armas e acumulavam títulos e patentes militares nas milícias do Rio de Janeiro. No entanto, o primeiro era o único da lista de 17 maiores comerciantes de grosso trato da cidade. ${ }^{52}$ Os Carneiro Leão eram muito ricos, mas não contavam com a honra inerente às famílias dos primeiros moradores.

$\mathrm{Na}$ América Portuguesa, os reinóis raramente receberam brasóes de armas. Seguramente os suplicantes eram naturais da América Portuguesa, atuavam como militares e receberam, com mais intensidade, a carta de brasão na regência joanina, período de enorme instabilidade em Portugal e no Brasil. Nesse sentido, a condecoração de militares das tropas auxiliares e das ordenanças aponta para o reconhecimento régio dos seus serviços, para a necessidade de valorizar os vassalos encarregados de manter a ordem interna e a proteção contra as ameaças externas nas diferentes capitanias.

Recorrendo às genealogias, conclui-se que as famílias mais antigas tiveram menor incidência na Bahia (20\% do total se suplicantes) e Rio de Janeiro (11\%), mas em Pernambuco (51\%) e no Maranhão (43\%) tiveram presença destacada. Em geral, os resultados quantitativos indicam que nas primeiras capitanias as justificaçóes da nobreza se pautaram nos serviços e feitos mais recentes, pois os militares das tropas auxiliares e das ordenanças raramente respaldavam os seus pedidos nos antepassados do século XVII ou mesmo da primeira metade do século XVIII. Talvez as hierarquias sociais aí tivessem sofrido maiores alterações do que em Pernambuco e no Maranhão, onde os suplicantes descendentes das antigas famílias ainda valorizavam os brasóes e tiveram condiçóes políticas e econômicas para pleiteá-los.

Assim, os suplicantes de Pernambuco e do Maranhão pertenciam a uma elite mais antiga, enquanto nas demais capitanias as elites tradicionais ou já não tinham poder para requer brasões de armas ou não os consideravam uma honraria capaz de alavancar a honra. A última hipótese está totalmente comprovada para a Bahia, pois os principais da terra não constam da lista dos abrasonados. Em princípio, a ausência das "primeiras e principais famílias" pode indiciar a sua decadência. Nesse caso, boa parte dos suplicantes fazia parte de grupos emergentes que recorriam às insígnias para acumular honra ao seu patrimônio material e político. Como eram nobres sem linhagem, recorriam aos brasóes, exibidos nas casas e nas roupas, para compensar a nobreza recente.

\footnotetext{
${ }^{52}$ BAENA, Visconde de Sanches de. Archivo heráldico-genealógico, op. cit., p. 116-166; FRAGOSO, João Luís Ribeiro. Homens de grossa aventura. Rio de Janeiro: Civilização Brasileira, 1998, p. 361.
} 


\section{Nobreza da terra}

No período colonial, a "nobreza da terra" era composta das principais lideranças políticas, militares e econômicas. Não raro eram proprietários de terras, engenhos, lavouras e escravos, controladores de sesmarias, portadores de patentes militares de tropas auxiliares ou das ordenanças, homens-bons das câmaras e membros das Misericórdias e Ordens Terceiras. Em geral, a nobreza provida pela monarquia (brasonados, fidalgos, cavaleiros e comendadores) estava aí inserida. Entretanto, as benesses régias nem sempre eram suficientes para viabilizar a ascensão social, para acumular patrimônio e alçar os vassalos aos postos de prestígio da sociedade colonial.

O poder limitado das mercês fica evidente quando militares pobres, chefes indígenas e mulatos, todos cavaleiros das ordens militares, não tomavam assento nas diferentes instâncias do poder local..$^{53}$ De fato, náo eram os títulos, mas a riqueza e o comando militar os elementos essenciais de distinção. O cabedal era mais importante do que a linhagem, e os hábitos e foros de fidalgo eram apenas o ápice do sucesso e não o seu promotor. ${ }^{54}$ Em síntese, os títulos raramente impulsionavam a trajetória de ascensão dos súditos. Como asseverou Stuart B. Schwartz, a nobreza "era uma questão de onde se vivia e o que se fazia, tanto quanto de um título nobiliárquico". 55 No ultramar, valia mais ter terras e escravos do que títulos. Aliás, percebe-se aí a relevância de se diferenciar a nobreza provida pela monarquia da nobreza da terra.

Os senhores de engenho eram uma aristocracia de riqueza e poder, mas não se constituíam estamento. Sua composição frequentemente era alterada por casamentos entre as filhas dos senhores com magistrados e comerciantes portugueses recém-estabelecidos. As conjunturas de crise e a falta de planejamento provocavam a ruína dos engenhos e inviabilizavam a permanência das famílias entre os principais da terra. Os títulos nobiliárquicos tampouco consolidavam-nas, pois essas benesses régias raramente eram herdadas. A nobreza da terra era formada por grupos instáveis, incapazes de sustentar a honra e o patrimônio da família por muitas geraçôes. ${ }^{56}$ Talvez a própria condição colonial e a distância de Lisboa gerassem entraves para que a nobreza do Novo Mundo gozasse plenamente de seus privilégios, do mesmo modo que faziam os reinóis.

\footnotetext{
${ }^{53}$ RAMINELLI, Ronald. Nobrezas do Novo Mundo, op. cit., p. 135-174.

${ }^{54}$ Sobre o assunto, Joáo Fragoso asseverou que a elites coloniais estavam inicialmente interessadas em ter grandes plantéis de cativos, lavouras e muitos lucros: “(...) depois de terem conseguido o primeiro objetivo, ou seja, terem enriquecido, procuravam ter um estilo de vida nobre." FRAGOSO, João Luís Ribeiro. Fidalgos e parentes de pretos: notas sobre nobreza principal da terra do Rio de Janeiro (1600-17500). In: FRAGOSO, Joáo Luís Ribeiro et al. (Org.). Conquistadores e negociantes. Rio de Janeiro: Civilização Brasileira, 2007, p. 103.

${ }_{55}$ SCHWARTZ, Stuart B. Segredos internos: engenhos e escravos na sociedade colonial, op. cit., p. 230.

${ }^{56}$ Vale mencionar a existência de algumas famílias que resistiram às adversidades do mundo colonial e mantiveram sob controle o patrimônio e os títulos por décadas, ver o estudo sobre os Pires de Carvalho Albuquerque e Maximiliano de Oliveira Leite: BORGES, Eduardo José Santos. Viver sob as leis da nobreza, op. cit., p. 206-218; ALMEIDA, Carla Maria Carvalho de. Uma nobreza da terra com projeto imperial: Maximiliano de Oliveira Leite e seus parentes. In: FRAGOSO, João Luís Ribeiro et al. (Org.) Conquistadores e negociantes. Rio de Janeiro: Civilização Brasileira, 2007, p. 121-193.
} 
Inicialmente, os conquistadores e proprietários de terras mantiveram-se no poder dos municípios, estribados nas sesmarias, nos postos da câmara e na formação de bandos que buscavam resistir à entrada de forasteiros. A partir de 1700, comerciantes e traficantes de escravos paulatinamente se fortaleceram e se instalaram no poder local e no interior da alta sociedade. Com o ouro e o fortalecimento do comércio, a riqueza tornou-se uma referência incontornável para se medir poder político nas cidades ultramarinas. De origem humilde e reinol, os grandes comerciantes e militares passaram a "comprar" hábitos e ameaçar a hegemonia dos descendentes dos conquistadores que se jactavam de sua fidalguia. Ao longo do século das luzes, a riqueza tornou-se bem mais poderosa do que as linhagens, a tradição e a memória da conquista.

Os fidalgos e cavaleiros das ordens militares tampouco formavam grupo homogêneo. No seiscentos, os cavaleiros eram em geral parte da açucarocracia, fossem senhores de engenhos, fossem proprietários de terras e de canaviais. Na Bahia e em Pernambuco, os soldados da fortuna e os comerciantes constituíam minorias entre os agraciados com os distintivos das ordens militares. E assim os donos de engenhos controlavam, ao mesmo tempo, a economia açucareira, os postos na administração local, as patentes militares e os títulos de cavaleiro. ${ }^{57}$ No setecentos essa coincidência se dissipou, e os senhores de engenho deixaram de valorizar as distinções sociais concedidas pela monarquia, conforme estudo já mencionado sobre os brasôes de armas.

A qualidade e os serviços militares foram paulatinamente superados como condição para ser alçado à nobreza. A riqueza tornou-se muito mais relevante para ingressar no segundo estado. Nas Minas Gerais, os homens de negócios portugueses se destacavam pela aquisição de títulos de cavaleiro mediante a compra de serviços militares de terceiros e do perdão régio para o defeito mecânico. Os proprietários de minas e escravos não chegavam a 8\%. Por certo não usavam seu cabedal para financiar a sua entrada na nobreza lusitana. Entretanto, os comerciantes eram 43\% dos suplicantes aos hábitos das ordens militares, seguidos pelos ouvidores e provedores da fazenda com 26\%.58 Enfim, nas Minas Gerais, a atividade econômica mineira não gerava a nobilitação da elite local, os mineiros estavam impossibilitados de comprar ou permaneciam alheios ao prestígio dos hábitos de cavaleiros.

Entre 1750 e 1779, a maioria dos homens ricos (67,8\%) da comarca de Vila Rica tinha como atividade principal a mineração, embora também atuasse em outras frentes da economia. ${ }^{59}$ Entre os brasonados da capitania, somente 30\% (9/29 brasonados) apresentaram uma longa filiação e apenas três dispunham de hábitos das ordens militares. Esses dados permitem uma boa comparação, sobretudo quando se parte do pressuposto de que a riqueza era condição essencial para se incluir na nobreza. Contrariando as expectativas, os mineiros

\footnotetext{
${ }^{57}$ KRAUSE, Thiago Nascimento. Em busca da honra, op. cit., p. 173-174; RICUPERO, Rodrigo. A formação da elite colonial. Brasil, c. 1530-c. 1630. São Paulo: Alameda, 2008, p. 243-319.

${ }^{58}$ STUMPF, Roberta Giannubilo. Cavaleiros do ouro e outras trajetórias nobilitantes, op. cit., p. 323-24.

${ }^{59}$ ALMEIDA, Carla Maria Carvalho de. Homens ricos em Minas colonial. In: BICALHO, Maria Fernanda et al. (Org.). Modos de governar: ideias e práticas políticas no império português. São Paulo: Alameda, 2005, p. 361-384.
} 
ricos não constavam em grande quantidade no rol dos cavaleiros das ordens militares, conforme o estudo de Stumpf. ${ }^{60}$ Aí havia o predomínio dos homens de negócios. Essa constatação permite concluir que os últimos, sobretudo os reinóis, eram mais inclinados às honrarias dos títulos do que os donos de minas. Assim, comparando os mineiros aos comerciantes, percebe-se que a riqueza não era o único motor da nobilitação. $\mathrm{O}$ gosto pelos títulos estava mais presente entre os portugueses do que entre os ricos moradores das Minas. ${ }^{61}$

Em Pernambuco, os lucros do comércio e as vantagens de se inserir à nobreza impulsionavam igualmente os homens de negócios a financiar a "compra" de títulos de cavaleiro. Vale ainda mencionar o aumento de comerciantes com hábito da Ordem de Cristo no século XVIII, sobretudo após a criação da câmara do Recife, "momento que marca o triunfo dos homens de negócio nas lutas pelo poder local e a rearrumação das alianças políticas da coroa na capitania”. ${ }^{62}$ Entre 429 comerciantes, somente 33 receberam o hábito da Ordem de Cristo, ou seja, somente 7,6\% se inseriram à nobreza como cavaleiros. ${ }^{63}$ Em média, passaram a dispor do privilégio do hábito com 45 anos de idade, após consolidar suas trajetórias como homens de negócio. ${ }^{64}$ Assim, as mercês de hábito eram o reconhecimento régio de uma trajetória de sucesso e não o motor da ascensão social. Depois de enriquecidos, os mercadores recorriam aos títulos para facilitar a entrada, sua e de seus filhos, nas principais famílias e nas câmaras municipais.

Aliás, a trajetória de José Vaz Salgado Júnior se diferencia bastante dos demais comerciantes do Recife porque tornou-se cavaleiro aos 30 anos. De fato o exemplo náo contraria a regra, pois ele era filho de um português, homem de negócios, proprietário de curtume, fazendas de gado, vereador, coronel de ordenança e mestre de campo dos terços auxiliares do Recife. Aos 30 anos, o jovem dispunha de prestígio e cabedal acumulados pelo pai e fazia parte de extensa parentela com participação no grande comércio e no poder municipal. Entre as patentes, ele detinha a de tenente-coronel do regimento de cavalaria auxiliar da Boa Vista. Era ainda selador e feitor da alfândega de Pernambuco e senhor de dois engenhos, em Ipojuca e São Lourenço da

\footnotetext{
${ }^{60}$ STUMPF, Roberta Giannubilo. Cavaleiros do ouro e outras trajetórias nobilitantes, op. cit.

${ }^{61}$ Vale lembrar o mesmo fenômeno na América espanhola. Moradores do Novo Mundo, os peninsulares eram os principais compradores de títulos de nobreza, denominados de titulados pela "razón del oro": FELICES DELA FUENTE, María del Mar. La nueva nobleza titulada de España y América en el siglo XVIII. Almería: Universidad de Almería, 2012, p. 326-360.

${ }^{62}$ SOUZA, George Felix Cabral de. Tratos e mofatras: grupo mercantil do Recife colonial (c. 1654-c. 1759). Recife: Edufpe, 2012, p. 245.

${ }^{63} \mathrm{O}$ número reduzido de cavaleiros foi verificado em outras capitanias da América Portuguesa. Entre 1737-1787, os cavaleiros da Ordem Cristo residentes ou assistentes no Continente do Rio Grande eram apenas seis. Quase todos dispensados do impedimento mecânico. Conforme estudo de Fábio Kühn, "A constituição da elite local, muito recente, náo permitira o acúmulo de serviços necessários para que os seus membros ambicionassem a honraria. Assim, somente identificamos um cavaleiro que recebeu o hábito devido aos seus próprios serviços (...)": KÜHN, Fábio. Gente da fronteira: família, sociedade e poder no sul da América Portuguesa. Tese (Doutorado) — Programa de Pós-graduaçáo em História, Universidade Federal Fluminense (UFF), Niterói, 2006, p. 358.

${ }^{64} \mathrm{O}$ estudo quantitativo realizou-se a partir do apêndice — resumos biográficos, publicado em SOUZA, George F. Cabral de. Tratos e mofatras: grupo mercantil do Recife colonial (c. 1654-c. 1759), op. cit., p. 321-585.
} 
Mata. ${ }^{65}$ Desde cedo estava inserido entre a nobreza da terra como rico comerciante, proprietário e vereador da câmara.

Como em Pernambuco, os oficiais da câmara do Rio de Janeiro tentaram em vão impedir a entrada de forasteiros. Para tanto, denunciaram ao soberano a presença de falsos nobres na urbe. De fato a nobreza da terra, descendentes dos conquistadores e primeiros moradores, tentavam barrar a entrada na câmara dos comerciantes portugueses. Para evitar golpes e o uso de falsos títulos, os homens-bons tentavam impor exigências contra o oportunismo dos mercadores. Para além de assegurar a veracidade dos hábitos, foros e brasões, os oficiais pediam para aqueles que se faziam de nobres fossem multados em 200 mil réis, soma entregue em parte à câmara. ${ }^{66}$

Com as descobertas de ouro nas Minas Gerais e o aumento do comércio, a cidade do Rio de Janeiro cresceu rapidamente, tornou-se porto de chegada de gentes provenientes do reino e do próprio ultramar. ${ }^{67}$ Assim, a urbe passou a ter grande mobilidade, ambiente propício ao aparecimento de "nobres sem papéis", súditos de nobreza duvidosa. O ethos nobiliárquico era difuso nas sociedades do Antigo Regime, sobretudo quando a riqueza se tornara um potente promotor de ascensão social. Na América, nas cidades coloniais em particular, a mobilidade social era ainda mais intensa. Ou melhor, a incipiência e a instabilidade das sociedades americanas permitem entender que os significados da nobreza nos trópicos multiplicaram-se.

Se a compra de hábitos das ordens militares era encabeçada por reinóis, os brasóes de armas raramente eram pleiteados pelos naturais de Portugal, residentes no Brasil e no Grão-Pará e no Maranhão. Aí, os brasonados eram nascidos na América Portuguesa, atuavam como militares e passaram a dispôs da carta de brasão sobretudo na regência joanina, conjuntura revolucionária responsável pela instabilidade política em Portugal e no Brasil. A concessão de brasóes de armas a militares das tropas auxiliares e das ordenanças torna-se relevante o reconhecimento régio dos seus serviços. Os brasões talvez fossem benesses capazes de valorizar os vassalos encarregados de manter a ordem interna e a proteção contra as ameaças externas nas diferentes capitanias. De todo modo, os brasões eram distinção régia pleiteada particularmente por homens sem as qualidades necessárias, sem títulos e sem linhagem. Era um mecanismo empregado por militares e homens ricos para enobrecer a si e a seu passado.

A dinâmica dos títulos cedidos pela monarquia portuguesa teve importantes alteraçóes na segunda metade do setecentos. Os serviços militares aos poucos cederam espaço para a compra de hábitos, e os ricos comerciantes tornaram-se paulatinamente homens enobreci-

\footnotetext{
${ }^{65}$ SOUZA, George Felix Cabral de. Tratos e mofatras: grupo mercantil do Recife colonial (c. 1654-c. 1759), op. cit., p. 494-96.

${ }^{66}$ RAMINELLI, Ronald. Nobrezas do Novo Mundo, op. cit., p. 96-132; FRAGOSO, João Luís Ribeiro. Fidalgos e parentes de pretos: notas sobre nobreza principal da terra do Rio de Janeiro (1600-17500), op. cit., p. 62.

${ }^{67}$ SAMPAIO, Antônio Carlos Jucá. Famílias e negócios: a formação da comunidade mercantil carioca na primeira metade do setecentos. In: FRAGOSO, João Luís Ribeiro et al. (Org.) Conquistadores e negociantes. Rio de Janeiro: Civilização Brasileira, 2007 p. 225-264; BICALHO, Maria Fernanda. A cidade e o império. Rio de Janeiro: Civilização Brasileira, 2003 p. 213.
} 
dos. Entre os brasonados, os descendentes dos conquistadores, parentes de cavaleiros das ordens militares dos séculos XVI e XVII tornaram-se minoria sobretudo nas principais capitanias, Bahia e Rio de Janeiro. Em contrapartida, militares sem antepassados ilustres, mas detentores de altas patentes nas tropas auxiliares e ordenanças, se destacam em todas as capitanias analisadas. Vale ainda mencionar a alteração do vínculo entre a distinçáo de sangue e as honrarias dos títulos, táo característica da nobreza europeia. As antigas linhagens da Bahia e do Rio de Janeiro estáo ausentes da relação dos brasonados da segunda metade do século XVIII. Talvez a antiga nobreza da terra não tivesse interesse em consumir seus recursos com honrarias régias. Por certo a honra, o prestígio e o patrimônio das famílias eram mais relevantes.

Fossem no século XVII ou no início do XIX, as elites brasílicas não se hierarquizavam com a mesma lógica da alta nobreza lusitana. As linhagens jamais tiveram o mesmo peso, as mercês remuneravam serviços, mas não asseguravam a manutenção das famílias. Não se pode desconsiderar as exceções, mas em geral as elites brasílicas eram instáveis e avessas à imortalidade do sangue nobre. Essas conclusóes são, porém, parciais, pois não temos estudos completos sobre a nobreza provida pela monarquia entre os séculos XVI e XIX. De todo modo, a partir de pesquisa documental e amplo balanço historiográfico, estou seguro do carácter incipiente dos títulos na promoção da ascensão social dos súditos ultramarinos.

\section{Referências bibliográficas}

AMARAL, Luís (Ed.). Livros de matrículas dos moradores da Casa Real: foros e ofícios 16411744. Lisboa: Guarda-Mor, 2009. 2t.

ALMEIDA, Carla Maria Carvalho de. Homens ricos em Minas colonial. In: BICALHO, Maria Fernanda et al. (Org.). Modos de governar: ideias e práticas políticas no império português. São Paulo: Alameda, 2005, p. 361-384.

. Uma nobreza da terra com projeto imperial: Maximiliano de Oliveira Leite e seus parentes. In: FRAGOSO, João Luís Ribeiro et al. (Org.) Conquistadores e negociantes. Rio de Janeiro: Civilizaçáo Brasileira, 2007, p. 121-193.

ANTONIL, André João. Cultura e opulência do Brasil por suas drogas e minas. Lisboa: CNCDP, 2001.

BAENA, Visconde de Sanches de. Archivo heráldico-genealógico. Lisboa: Typographia Universal, 1872.

BICALHO, Maria Fernanda. A cidade e o império. Rio de Janeiro: Civilização Brasileira, 2003.

BOULLE, Pierre-Henri. Boulle. Race et esclavage dans la France de l'Ancien Régime. Paris: Perrin, 2007.

BORGES, Eduardo José Santos. Viver sob as leis da nobreza. Tese (Doutorado) — Programa de Pós-graduação em História, Universidade Federal da Bahia (Ufba), Salvador, 2015. 


\section{NOBREZA E PRINCIPAIS DA TERRA \\ - América Portuguesa, séculos XVII e XVIII \\ Ronald Raminelli}

BÖTTCHER, N. et al. (Coord.). El peso de la sangre: limpios, meztizos y nobles en el mundo hispánico. Ciudad de México: El Colégio de México, 2011.

BRANCO, Manuel da Silva Castelo. Os trabalhos de D. Lázaro Leitão Aranha sobre as três ordens militares: Avis, Cristo e Santiago. In: FERNANDES, Isabel Cristina Ferreira (Ed.). Ordens militares, guerra, religião, poder e cultura. Lisboa: Ediçóes Colibri, 1999, p. 63-78.

CALMON, Pedro. Introdução e notas ao catálogo genealógico das famílias de Frei Jaboatão, Salvador: Empresa Gráfica da Bahia, 1985.

COUTINHO, Mílson. Fidalgos e baróes: uma história da nobiliarquia luso-maranhense. São Luís: GEIA, 2005.

DEFINIÇÓES e estatutos dos cavaleiros \& freires de N. S. Jesus Christo. Lisboa: Craesbeeck, 1628. DUTRA, Francis. Membership in the Order of Christ in the Seventeenth Century. The Americas, v. 27, Washington, p. 3-25, 1970.

. A Hard-fought for Recognition. The Americas, Washington, v. 56, p. 91-113, 1999. . Ser mulato nos primórdios da modernidade portuguesa. Tempo, Niterói, v. 30, p. 101-114, 2011.

FELICES DELA FUENTE, María del Mar. La nueva nobleza titulada de España y América en el siglo XVIII. Almería: Universidad de Almería, 2012.

FONSECA, Antônio J. V. Borges da. Nobiliarchia pernambucana. In: Anais da Biblioteca Nacional, Rio de Janeiro, v. XLVII, p. 7-502, 1925.

. Nobiliarchia pernambucana. In: Anais da Biblioteca Nacional, Rio de Janeiro, v. XLVIII, p. 5-488, 1926.

FRAGOSO, João Luís Ribeiro. Homens de grossa aventura. Rio de Janeiro: Civilização Brasileira, 1998.

- Fidalgos e parentes de pretos: notas sobre nobreza principal da terra do Rio de Janeiro (1600-17500). In: FRAGOSO, João Luís Ribeiro et al. (Org.). Conquistadores e negociantes. Rio de Janeiro: Civilização Brasileira, 2007, p. 33-120.

JOUANNA, Arlette. O imaginário do sangue e de sua pureza na antiga França. Tempo, Niterói, n. 30, p. 21-40, 2011.

KICZA, John E. The Great Families of Mexico: Elite Maintenance and Business Practices in Late Colonial Mexico City. Hispanic American Historical Review, Durham, v. 63, n. 3, p. 429-457, 1982.

KENNETH, John Norman. Bahian Elites, 1750-1822. Hispanic American Historical Review, Durham, v. 53, n. 3, p. 415-439, 1973.

KRAUSE, Thiago Nascimento. Em busca da honra. São Paulo: Annablume, 2012.

KÜHN, Fábio. Gente da fronteira: família, sociedade e poder no sul da América Portuguesa. Tese (Doutorado) — Programa de Pós-graduação em História, Universidade Federal Fluminense (UFF), 2006. 
LACROIX, Maria de Lourdes Lauande. Jerônimo de Albuquerque Maranhão, guerra e fundação no Brasil Colonial. São Luís: Uema, 2006.

MARTÍNEZ, María Elena. Genealogical fictions. Stanford: Stanford University Press, 2008. MATTOS, Hebe. Black Troops and Hierarchies of Color in the Portuguese Atlantic World: the Case of Henrique Dias and His Black Regiment. Luso-Brazilian Review, v. 45, n. 1, p. 6-29, 2008. MAXWELL, Kenneth. A devassa da devassa. Rio de Janeiro: Paz e Terra, 1978.

MELLO, José Antônio Gonsalves de. Restauradores de Pernambuco: Filipe Camarão. Recife: Imprensa Universitária, 1967.

OLIVAL, Fernanda. As ordens militares e o Estado Moderno. Lisboa: Estar, 2001.

- O Brasil, as Companhias pombalinas e a nobilitação no terceiro quartel do setecentos. Anais, Évora, n. 8/9, p. 73-97, 1998-1999.

OSÓRIO, D. Jerónimo. Tratados da nobreza civil e cristã. Lisboa: Imprensa nacional/Casa da Moeda, 1996.

PEDREIRA, Jorge Miguel Viana. Estrutura industrial e mercado colonial: Portugal e Brasil (1780-1830). Lisboa: Difel, 1994.

RAMINELLI, Ronald. Nobrezas do Novo Mundo. Rio de Janeiro: FGV/Faperj, 2015.

. Matias Vidal de Negreiros: mulato entre a norma reinol e as práticas ultramarinas. Varia Historia, Belo Horizonte, v. 32, p. 699-730, 2016. $1-26,2016$.

. Justificando nobrezas: velhas e novas elites coloniais. História, São Paulo, v. 35, p. RHEINGANTZ, Carlos Grandmasson. Primeiras famílias do Rio de Janeiro (séculos XVI e XVII). Rio de Janeiro: Livraria Brasiliana Editora, 1965-1967. 2v.

RICUPERO, Rodrigo. A formação da elite colonial. Brasil, c. 1530-c. 1630. Sáo Paulo: Alameda, 2008.

SAMPAIO, Antônio Carlos Jucá. Famílias e negócios: a formação da comunidade mercantil carioca na primeira metade do setecentos. In: FRAGOSO, João Luís Ribeiro et al. (Org.). Conquistadores e negociantes. Rio de Janeiro: Civilização Brasileira, 2007, p. 225-264.

SAMPAYO, Antonio de Villasboas e. Nobiliarchia Portugueza: tratado de nobreza hereditária, \& política. Lisboa: Oficina Francisco Vilella, 1676.

SÃO PAYO, Marquês de. Do direito heráldico português. Lisboa: Centro Tip. Colonial, 1927.

SCHALK, Ellery. L'épée et le sang: une histoire du concept de noblesse. Paris: Champ Vallon, 1986.

SCHWARTZ, Stuart B. New World Nobility: Social Aspirations and Nobility in the Conquest and Colonization of Spanish America. In: CHRISMAN, Miriam Usher; GRÜNDLER, Otto (Ed.). Social Groups and Religious Ideas in the Sixteenth Century. Kalamazoo: The Medieval Institute Western Michigan University, 1978. 
. Segredos internos: engenhos e escravos na sociedade colonial. São Paulo: Companhia das Letras, 1988.

SOUZA, George Felix Cabral de. Tratos e mofatras: grupo mercantil do Recife colonial (c. 1654-c. 1759). Recife: Edufpe, 2012.

STUMPF, Roberta Giannubilo. Cavaleiros do ouro e outras trajetórias nobilitantes. Belo Horizonte: Traço Fino, 2014.

VARNHAGEN, Francisco Adolfo de. História geral do Brasil. Belo Horizonte: Itatiaia; São Paulo: Edusp, 1981. 3v.

VERA, Álvaro Ferreira de. Origem da nobreza política. Lisboa: Livro Aberto, 2005.

\section{Como citar:}

RAMINELLI, Ronald. Nobreza e principais da terra - América Portuguesa, séculos XVII e XVIII. Topoi. Revista de História, Rio de Janeiro, v. 19, n. 38, p. 217-240, mai./ago. 2018. Disponível em: <www.revistatopoi.org>. 